\title{
INDIGENOUS DEVELOPMENT OF SESAME SEED HARVESTING MACHINE
}

\author{
SETHURAMAN. $\mathbf{N}^{1}$, THIRUMARAN. $\mathbf{V}^{2} \&$ JAYAMOORTHY. $\mathbf{M}^{3}$ \\ ${ }^{1}$ Associate Professor, IFET College of Engineering, Villupuram, Tamil Nadu, India \\ ${ }^{2,3}$ Assistant Professor, IFET College of Engineering, Villupuram, Tamil Nadu, India
}

\begin{abstract}
In the usual agricultural practices, the sesame seeds are being cut manually with the help of specialized knife cutters by skilled farmers. The farmers are finding it tough to do the harvesting process under the hot sunlight. Hence modern sesame harvesting machines were introduced to the carry out the harvesting process. But those machines were too large in size when compared to the size of the sesame plant. In order to overcome the above mentioned disadvantages, a modified sesame harvesting machine is designed and fabricated in this work and it is aimed at reducing the harvesting time in the agricultural field and also to reduce the efforts of the farmers to a large extent.

KEYWORDS: Harvesting, Chain Sprocket, Agricultural Field.
\end{abstract}

Received: Jun 09, 2020; Accepted: Jun 29, 2020; Published: Aug 06, 2020; Paper Id.: IJMPERDJUN2020646

\section{INTRODUCTION}

Sesame is one of the oldest crops known to humans. It is one of the earliest domesticated plants. It is a short duration crop grown throughout the year. The seeds of the plant yield edible oil. Due to the presence of potent antioxidant, sesame seeds are known as "the seed of immortality". Two distinct types of seed are recognized, the white and the black. There are also intermediate coloured varieties varying from red to rose or from brown or grey. Sesame was a major oilseed in the ancient world because of its ease of extraction, great stability, and drought resistance. In India today, almost as in the olden days, a farmer can take his crop to an expeller that consists of grinding mortar and pestle stones driven by a bullock. He can place the oil in a vessel, take it back to his home and have cooking oil for a year without the oil going rancid Safe produce begins with the production and handling practices on the farm. The sesame was cut with a binder, hand shocked, and manually fed into a combine when dry. A sesame seed grown and sold with little biological contamination is less likely to result in health hazards caused by poor handling during later preparation stages. Farmers/producers have the critical job of minimizing product contamination by learning about potential sources of contamination and by using Good Agricultural Practices a set of recommendations that can help improve the quality and safety of the produce grown. Good agricultural practices at the farm level involve multi-faceted efforts at ensuring that foods are safe for human consumption.

\section{Manual Method of Crop Cutting}

To the cutting and threshing machine for seed separation this method the crop are remove as mentioned in the traditional method. These method crops are tied together to from a bundle. These bundles are garnered and taken to threshing machine. This machine separates the seed from the crops. 


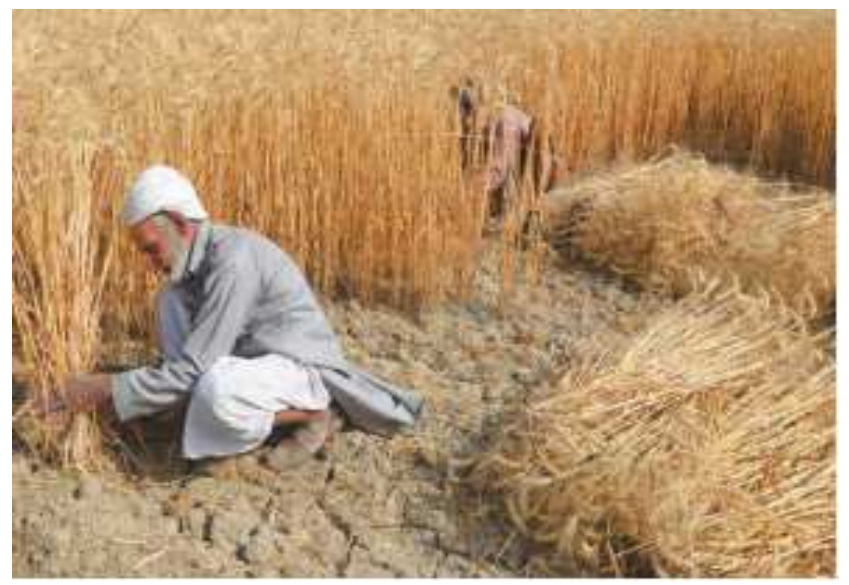

Figure 1

\section{LITERATURE REVIEW}

- Yang Ran et al., Mining parts are the most important components of the tuber harvesting machine, and the study of the mining shovel shape is the chief research. This paper first proposes mining parts design requirements, and makes a summary about the shape of domestic and international mining shovels, whose respective advantages and disadvantages are analyzed. Swing mining shovels are the common used harvesting machine, and then structure and working principles of harvesting machine with different parts of the swing form are analyzed. More analysis is made in the operating principles of the underway new mining way-modular mining parts. The future research directions of mining parts are also presented.

- Rajya Lakshmi et al., Harvesting is the important part in the agricultural industry. Modern harvesting technology is increasing day by day. But the cost of the harvesting machines is high. So, these can be only limited and suitable for the farmers having large agricultural land area i.e., more than two hectares. So, the farmers having less cultural area cannot rent buy these harvesters for cutting of crops. So, the main aim of our project is to fabricate "Low Cost Manual Crop Harvesting Machine" which is efficiently suitable for the farmers having less area i.e., less than two hectares for cultivation. This machine uses the power to drive the cutters from the wheels of the vehicle itself. The cutting motion to the rotary blades is obtained through the bevel gears (or) crown wheel and pinion arrangement. By this project we can reduce the difficulties faced by farmers having less cultivation area by increasing productivity, time taken for harvesting and mainly overall cost for harvesting is minimized.

- Teo Pang et al., Due to the productivity gain, combine harvesting machines are increasingly adopted for tree cutting all around the world. In this paper, work study is applied to improve the operation efficiency of combine harvesting machines for a case problem. The operations are analyzed by using MOD method such that standard operation time for all the activities determined. Then the process analysis is done such that the existing process is redesigned. In this way, productivity can be increased by $19 \%$, a significant improvement. 


\section{Bill of Materials}

Table 1

\begin{tabular}{|l|l|c|}
\hline Components & \multicolumn{1}{|c|}{ Specification } & Quantity \\
\hline Roller & Mild steel & 2 \\
\hline Gear & Spur gear/cast Iron & 2 \\
\hline Motor & Steel & 1 \\
\hline Blade /Cutter & 40 RPM & 1 \\
\hline Conveyor Belt & Cotton or Fabric/flat belt & 1 \\
\hline
\end{tabular}

\section{PROCESS DESCRIPTION}

\section{Motor}

An electric motor is an electrical machine that converts electrical energy into mechanical energy. The reverse of this is the conversion of mechanical energy into electrical energy and is done by an electric generator, which has much in common with a motor. Electric motors operate through the interaction between an electric motor's magnetic field and winding currents to generate force.

\section{Chain}

Chain conveyer is used to move cutted plant. The chain conveyer took the plant to the crank by the manual movement of wheel force. Chains are mostly made from plain carbon or alloy steel, but some are nickel-plated to prevent rust, or simply for aesthetics. Using chain drive allowed the mechanical advantage between the drive and driven sprockets to determine the maximum speed, thereby enabling manufacturers to reduce the size of the driving wheel for safety.

\section{Belt \& Pulley}

A belt and pulley system is characterized by two or more pulleys in common to a belt. This allows for mechanical power, torque, and speed to be transmitted across axles. If the pulleys are of differing diameters, a mechanical advantage is realized. A belt drive is analogous to that of a chain drive, however a belt sheave may be smooth so that the mechanical advantage is approximately given by the ratio of the pitch diameter of the sheaves only, not fixed exactly by the ratio of teeth as with gears and sprockets. In the case of a drum-style pulley, without a groove or flanges, the pulley often is slightly convex to keep the flat belt centered.

\section{Crank}

Slider-crank mechanism, arrangement of mechanical parts designed to convert straight-line motion to rotary motion, as in a reciprocating piston engine, or to convert rotary motion to straight-line motion, as in a reciprocating piston pump. The basic nature of the mechanism and the relative motion of the parts can best be described with the aid of the accompanying in which the moving parts are lightly shaded.

\section{Sieve}

Sieving is a simple technique for separating particles of different sizes. A sieve such as used for sifting flour has very small holes. Coarse particles are separated or broken up by grinding against one-another and screen openings. Depending upon the types of particles to be separated, sieves with different types of holes are used. Sieves are also used to separate stones from sand. Sieving plays an important role in food industries where sieves (often vibrating) are used to prevent the contamination of the product by foreign bodies. 


\section{Shaft}

A shaft is a rotating machine element, usually circular in cross section, which is used to transmit power from one part to another, or from a machine which produces power to a machine which absorbs power.Transmission shafts are used to transmit power between the source and the machine absorbing power; e.g. counter shafts and line shafts. Machine shafts are the integral part of the machine itself.

\section{WORKING}

The square shape base is made for the withstanding whole setup of project. The wheels were attached to the base by the shaft for movement. The cutting blade is attached at the front end for the cutting purpose. The chain conveyer is to left cute plant. The crank is for the operation of seeds from the plant. The motor helps in production of rotary motion. The machine is made to move manually over the sesame plant land. The motor is connected with the pulley which gives the movement for the sieve, crank and cutting blades. The motor is started the pulley will transfer the energy to the cutting blade through the sieve end. The cutting blades for cut the plant and the plant were taken by conveyer. The chain conveyer took the plants to the crank by the manual movement of wheel force. The crank in which is operated through motor pulley and the oscillated motion help for the cutting of seeds from the plant. The plants and seeds will send to the sieve through the tray.

\section{EXPERIMENTAL SETUP}

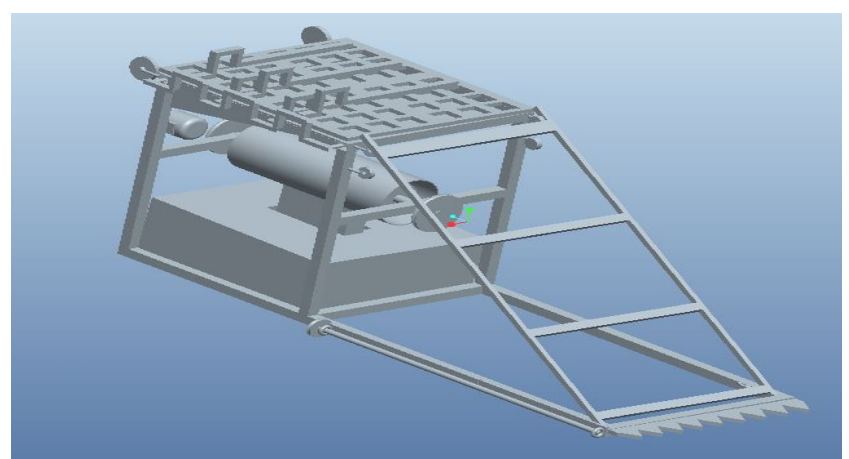

Figure 2

\section{DESIGN CALCULATION}

\section{- Design of Chain Drive}

Power $=1 \mathrm{hp}=746 \mathrm{watt}=0.746 \mathrm{~kW}$

$$
\begin{aligned}
& \mathrm{N}_{1}=70 \mathrm{rpm}, \mathrm{N}_{2=35} \mathrm{rpm} \\
& \text { Life=8 hrs/day, } \mathrm{a}=800 \mathrm{~mm}
\end{aligned}
$$

\section{Transmission Ratio}

$$
\begin{aligned}
& \mathrm{i}=\mathrm{n}_{1} / \mathrm{n}_{2} \\
& =70 / 35 \\
& \mathrm{i}=2
\end{aligned}
$$




\section{Selection of Teeth on Driver Sprocket}

$$
\mathrm{Z}_{1}=20(\text { for } \mathrm{i}=2 \text { to } 3 \text { ) }
$$

\section{No of Teeth on the Driver Sprocket}

$$
\begin{aligned}
\mathrm{Z}_{2} & =i * \mathrm{Z}_{1} \\
& =2 * 20 \\
\mathrm{Z}_{2} & =40
\end{aligned}
$$

\section{Optimum Center Distance}

$$
\begin{aligned}
\mathrm{a}= & (30-50) \mathrm{p} \\
\mathrm{a}= & 500 \mathrm{~mm} \\
\mathrm{p}_{\max } & =\mathrm{a} / 30 \\
& =800 / 30 \\
\mathrm{P}_{\text {max }} & =26.67 \mathrm{~mm} \\
\mathrm{P}_{\min } & =\mathrm{a} / 50 \\
& =800 / 50 \\
\mathrm{P}_{\text {min }} & =16 \mathrm{~mm}
\end{aligned}
$$

Assume a standard pitch close to $\mathrm{p}_{\text {max }}$

$$
\mathrm{P}=19.05 \mathrm{~mm}
$$

5. Total load

$$
\mathrm{P}_{\mathrm{T}}=\mathrm{P}_{\mathrm{t}}+\mathrm{P}_{\mathrm{c}}+\mathrm{P}_{\mathrm{s}}
$$

\section{Tangential Force}

$$
\begin{aligned}
& \mathrm{P}_{\mathrm{t}}=1020 * \mathrm{~N} / \mathrm{V} \\
& \mathrm{V}=\text { no. of teeth on sprocket*P*Rpm } / 60 * 1000 \\
& =20 * 19.05 * 70 / 60 * 1000 \\
& \mathrm{~V}=0.44 \mathrm{~m} / \mathrm{s} \\
& \mathrm{P}_{\mathrm{t}}=1020 * 0.746 / 0.44 \\
& \mathrm{P}_{\mathrm{t}}=1710 \mathrm{~N}
\end{aligned}
$$

\section{Centrifugal Tension}

$$
\begin{aligned}
& \mathrm{P}_{\mathrm{c}}=\mathrm{wv}^{2} / \mathrm{g}=\mathrm{mv}^{2} \\
& \mathrm{~m}=1 \mathrm{~kg} / \mathrm{m}
\end{aligned}
$$




$$
\mathrm{P}_{\mathrm{c}}=1 * 0.44^{2}
$$

Tension due to sagging

$$
\begin{aligned}
& \mathrm{P}_{\mathrm{s}}=\mathrm{Kwa} \\
& \mathrm{k}=6 \\
& \mathrm{~W}=\mathrm{mg}=1 * 9.81 \\
& \mathrm{~W}=9.81 \mathrm{~N} / \mathrm{m} \\
& \mathrm{a}=0.8 \mathrm{~m} \\
& \mathrm{P}_{\mathrm{S}} 6 * 9.81 * 0.8 \\
& =47 \mathrm{~N} \\
& \mathrm{P}_{\mathrm{T}}=\mathrm{P}_{\mathrm{t}}+\mathrm{P}_{\mathrm{c}}+\mathrm{P}_{\mathrm{S}} \\
& =1710+0.2+47 \\
& =1757.2 \mathrm{~N}
\end{aligned}
$$

\section{Design Load}

$$
\begin{aligned}
& =\mathrm{K}_{\mathrm{s}} * \mathrm{P}_{\mathrm{S}} \\
& \qquad \mathrm{K}_{\mathrm{S}}=\mathrm{K}_{1} * \mathrm{~K}_{2} * \mathrm{~K}_{3} * \mathrm{~K}_{4} * \mathrm{~K}_{5} * \mathrm{~K}_{6} \\
& \mathrm{k}_{1}=1 \text { (for variable loads with mild shocks) } \\
& \mathrm{k}_{2}=1 \text { (for adjustable supports) } \\
& \mathrm{k}_{3}=1\left(\text { because we have taken } \mathrm{a}_{\mathrm{p}}=(30-50) \mathrm{p}\right) \\
& \mathrm{k}_{4}=1(\text { drive is horizontal) } \\
& \mathrm{k}_{5}=1.5(\text { for drop lubrication) } \\
& \mathrm{k}_{6}=1(\text { for } 8 \text { hrs } / \text { day working) } \\
& \mathrm{k}_{\mathrm{s}}=1 * 1 * 1 * 1 * 1.5 * 1 \\
& \mathrm{k}_{\mathrm{s}} 1.5 \\
& \begin{array}{l}
\mathrm{D}_{\mathrm{L}}=\mathrm{ks} * \mathrm{P}_{\mathrm{T}} \\
=1.5 * 1757.2 \\
=2635.8 \\
=2635 \mathrm{~N}
\end{array}
\end{aligned}
$$

\section{Factor of Safety}




$$
\begin{aligned}
& =63600 / 2635 \\
& =24.1
\end{aligned}
$$

$$
\mathrm{N}=70, \mathrm{P}=19.05
$$

Required minimum $\mathrm{FOS}=7.0$

\section{Bearing Stress on Rollers}

Induced stress,

$$
\begin{aligned}
\sigma & =p t * k s / \mathrm{A}\left[\mathrm{A}=210 \mathrm{~mm}^{2}\right] \\
& =1710 * 1.5 / 210 \\
\sigma & =12.2 \mathrm{~N} / \mathrm{mm}^{2}
\end{aligned}
$$

\section{Length of Chain}

$$
\begin{aligned}
\mathrm{Lp} & =2 \mathrm{ap}+\left(\mathrm{z}_{1}+\mathrm{z}_{2} / 2\right)+\left(\mathrm{z}_{2}-\mathrm{z}_{1} / 2 \pi\right) / \mathrm{a}_{\mathrm{p}} \\
\mathrm{a}_{\mathrm{p}} & =\mathrm{a}_{0} / \mathrm{p} \\
& =\text { center distance/pitch } \\
& =800 / 19.05 \\
& =42 \\
\mathrm{lP} & =2 * 42+(20+40 / 20)+(40-20 / 2 \pi)^{2} / 42 \\
& =84+30+0.24 \\
& =114.24 \text { links } \\
& =116 \text { links (rounded off to an even number) }
\end{aligned}
$$

\section{Actual Length of Chain}

$$
\begin{aligned}
\mathrm{L} & =116^{*} \mathrm{p} \\
& =116^{*} 19.05 \\
& =2.2 \mathrm{~m}
\end{aligned}
$$

\section{Exact Distance}

$$
\begin{aligned}
\mathrm{A} & =\mathrm{e}+\sqrt{e^{2}-8 \mathrm{~m} / 4} * \mathrm{p} \\
\mathrm{e} & =\mathrm{lp}-\left(\mathrm{z}_{1}+\mathrm{z}_{2} / 2\right) \\
& =116-(20+40 / 2) \\
& =86
\end{aligned}
$$




$$
\begin{aligned}
\mathrm{M} & =\left(\mathrm{z}_{2}-\mathrm{z}_{1} / 2 \pi\right)^{2} \\
& =(40-20 / 2 \pi)^{2} \\
& =10.13 \\
& =\left(86+\sqrt{\left.86^{2}-8 * 10.13 * 19.05\right) / 4}\right. \\
& =816.81 \\
\mathrm{a} & =820 \mathrm{~mm}
\end{aligned}
$$

\section{Sprocket Distance}

Small sprocket,

$$
\begin{aligned}
\mathrm{d} & =\mathrm{p} / \sin \left(180 / \mathrm{z}_{1}\right) \\
& =19.05 / \sin (180 / 20) \\
& =122 \mathrm{~mm}
\end{aligned}
$$

Outside diameter

$$
\begin{aligned}
& \mathrm{do}_{1}=\mathrm{d}_{1}+0.8 \mathrm{~d}^{* \mathrm{r}} \\
& \mathrm{d}^{* \mathrm{r}}=11.9 \\
&=122+0.8 * 11.9 \\
&=131.5 \mathrm{~mm}
\end{aligned}
$$

Larger sprocket,

$$
\begin{aligned}
\mathrm{d}_{2} & =\mathrm{p} / \sin \left(180 / \mathrm{z}_{2}\right) \\
& =19.05 / \sin (180 / 40 /) \\
& =242.8 \mathrm{~mm} \\
& =243 \mathrm{~mm} \\
\mathrm{do}_{2} & =\mathrm{d}_{2}+0.8 * 11.9 \\
& =243+0.8 * 11.9 \\
& =253 \mathrm{~mm}
\end{aligned}
$$

\section{- DESIGN OF PULLEY}

$$
\begin{aligned}
& \text { Power }=1 \mathrm{hp}=746 \text { watt } \\
& \text { Speed }=70 \mathrm{Rpm} \\
& \mathrm{d}=280 \mathrm{~mm}
\end{aligned}
$$

No .of arm, $\mathrm{n}=4$, allowable bending stress, $\sigma_{\mathrm{b}}=15 \mathrm{~N} / \mathrm{mm}^{2}$ 


$$
\begin{aligned}
\mathrm{T} & =\mathrm{p} * 60 / 2 \pi * \mathrm{~N} \\
& =746 * 60 / 2 \pi * 70 \\
& =102 \text { N.m }
\end{aligned}
$$

Bending Moment

$$
\begin{aligned}
\mathrm{m} & =2 \mathrm{~T} / \mathrm{n} \\
& =2 * 102 / 4 \\
\mathrm{~m} & =51 * 10^{3} \text { N.m }
\end{aligned}
$$

\section{Section of Modulus}

$$
\begin{aligned}
\mathrm{Z} & =\pi / 32 * \mathrm{~b}_{1} * \mathrm{a}_{1}{ }^{2} \\
& =\pi / 32 * \mathrm{~b}(2 \mathrm{~b})^{2} \\
\mathrm{z} & =\pi \mathrm{b}^{3} / 8
\end{aligned}
$$

\section{Bending Stress}

$$
\begin{aligned}
& \sigma_{\mathrm{b}}=\mathrm{M} / \mathrm{Z} \\
& 15=51 * 10^{3} * 8 / \pi * \mathrm{~b}^{3} \\
& \mathrm{~b}^{3}=8658.62 \\
& \mathrm{~b}=20.5 \mathrm{~mm} \\
& \mathrm{a}=2 \mathrm{~b} \\
& \mathrm{a}=2 * 20.5 \\
& \mathrm{a}=41 \mathrm{~mm}
\end{aligned}
$$

\section{- DESIGN OF V-BELT}

$$
\begin{aligned}
& D=280 \mathrm{~mm} \\
& \mathrm{~d}=30 \mathrm{~mm} \\
& C=400 \mathrm{~mm} \\
& P=0.746 \mathrm{~kW} \\
& \mathrm{n}_{1}=140 \mathrm{rpm} \\
& \mathrm{n}_{2}=50 \mathrm{rpm}
\end{aligned}
$$

\section{Selection of Belt Section}

A -section is selected. 
For this section dimension

\section{Nominal Pitch Length Scale}

$\mathrm{L}=2 \mathrm{c}+(\pi D * d / 2)+(\mathrm{D}-\mathrm{d})^{2} / 4 \mathrm{c}$

$$
\begin{aligned}
& =2 * 400+400+\pi(280+30) / 2+((280-30) /(4 * 400))^{2} \\
& =800+487+39 \\
& =1326 \mathrm{~mm}
\end{aligned}
$$

A-section 36

$$
\begin{aligned}
\mathrm{L} & =1326=36 \\
& =1362 \mathrm{~mm}
\end{aligned}
$$

\section{Section of Various Modification Factor}

Correction factor for length,

$$
\mathrm{F}_{\mathrm{C}}=0.96
$$

Service factor,

$$
\mathrm{Fa}=1.0
$$

Arc of contact,

$$
\begin{aligned}
& =180-(\mathrm{D}-\mathrm{d} / \mathrm{c}) * 60 \\
& =180-(280-30 / 400) * 60 \\
& =142.5 \\
& =2.48 \text { radian }
\end{aligned}
$$

Factor, $\mathrm{F}_{\mathrm{d}}=0.89$

\section{Calculation of Power Capacity}

$$
\begin{aligned}
& \mathrm{Kw}=\left(0.45 * \mathrm{~s}^{-0.009}-(19.62 / \mathrm{de})-0.765 * 10^{-4} * \mathrm{~s}^{2}\right) * \mathrm{~s} \\
& \mathrm{de}=\mathrm{dp} * \mathrm{fb} \\
& \mathrm{dp}=30 \mathrm{~mm} \\
& \mathrm{fb}=1.14
\end{aligned}
$$

For $\mathrm{D} / \mathrm{d}=280 / 30$

$=9.33$

de $=30 * 1.14$

$\mathrm{de}=34.2 \mathrm{~mm}$ 


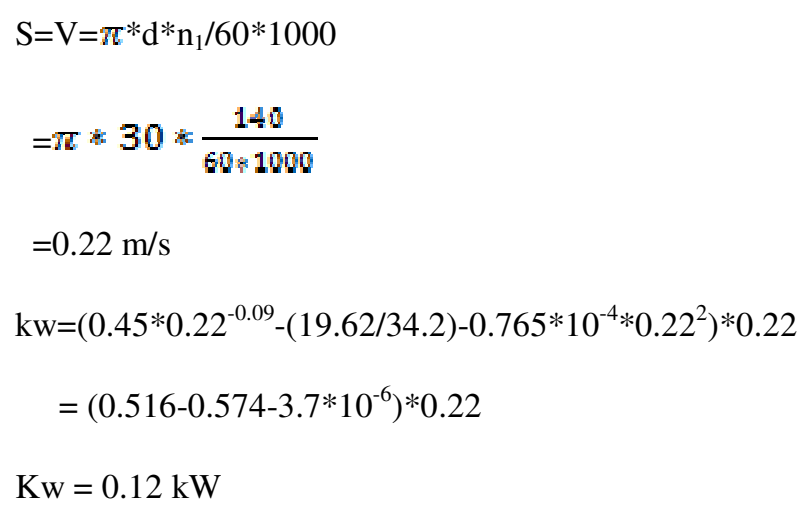

\section{Determination of Belts}

$$
\begin{aligned}
\mathrm{N}_{\mathrm{b}} & =\mathrm{p} . \mathrm{f}_{\mathrm{a}} / \mathrm{kw}^{*} \mathrm{f}_{\mathrm{c}} * \mathrm{f}_{\mathrm{d}} \\
& =0.746 * 1 / 0.12 * 0.96 * 0.89 \\
\mathrm{~N}_{\mathrm{b}} & =7
\end{aligned}
$$

\section{Calculation of Stresses}

$$
\begin{gathered}
\mathrm{T}_{1}-\mathrm{mV}^{2} / \mathrm{T}_{2}-\mathrm{mV}^{2}=e^{\mu \kappa \alpha / \sin \left(\frac{\theta}{2}\right)} \\
\alpha=2.48 \mathrm{rad} \\
\mu=0.3 \text { (assumed) } \\
\theta=40^{\circ}
\end{gathered}
$$$$
\mathrm{M}=0.106 \mathrm{~kg} / \mathrm{m}
$$$$
=\mathrm{T}_{1}-0.106 * 0.22^{2} / \mathrm{T}_{2}-0.106 * 0.22^{2}
$$$$
=\mathrm{e}^{0.3 * 2.48 / \sin 200}
$$$$
=\mathrm{T}_{1}-5.1 * 10^{-3} / \mathrm{T}_{2}-5.1 * 10^{-3}
$$$$
\mathrm{M}=8.8
$$$$
\mathrm{T}_{1}-5.1 * 10^{-3}=8.8 \mathrm{~T}_{2}-0.045
$$$$
\mathrm{T}_{1}=8.8 \mathrm{~T}_{2}-0.04
$$

Power $=\left(\mathrm{T}_{1-} \mathrm{T}_{2}\right) * \mathrm{~V}$

$746 / 7=\left(\mathrm{T}_{1}-\mathrm{T}_{2}\right) * 0.22$

$\mathrm{T}_{1}-\mathrm{T}_{2}=484.4$

$\mathrm{T}_{2}=\mathrm{T}_{1}-484.8$

From- 


$$
\begin{aligned}
& \mathrm{T}_{1}=8.8 \mathrm{~T}_{1}-4262.8-0.04 \\
& 7.8 \mathrm{~T}_{1}=4262 \\
& \mathrm{~T}_{1}=5465 \mathrm{~N}
\end{aligned}
$$

A section area, $A=80 \mathrm{~mm} 2$

Stress induced,

$$
\begin{aligned}
\sigma & =T_{1} / \text { Area } \\
& =546.5 / 80 \\
\sigma & =6.83 \mathrm{~N} / \mathrm{mm} 2
\end{aligned}
$$

\section{Calculation of Actual Center Distance}

$$
\begin{aligned}
\mathrm{A}=\mathrm{L} / 4-\pi & (\mathrm{D}+\mathrm{d} / 8) \\
& =1326 / 4-\pi(280+30 / 8) \\
& =331.5-121.7 \\
& =209.8 \mathrm{~mm} \\
\mathrm{~B}=(\mathrm{D}-\mathrm{d})^{2} / 8 & \\
& =(280-30)^{2} / 8 \\
& =7812.5 \mathrm{~mm} \\
\mathrm{C}=\mathrm{A}+\sqrt{A^{2}-B} & \\
& =209.8+\sqrt{209.8^{2}-7812.5}
\end{aligned}
$$

Actual Center Distance

$$
\mathrm{C}=400 \mathrm{~mm}
$$

\section{- STORAGE TANK CAPACITY}

$$
\begin{aligned}
& V=l^{*} b^{*} h \\
& L=750 \mathrm{~mm} \\
& b=750 \mathrm{~mm} \\
& h=300 \mathrm{~mm} \\
& v=168.7 * 10^{\wedge} 6 \mathrm{~mm}^{3} \\
& v=0.168 \mathrm{~m}^{3}
\end{aligned}
$$




\section{CONCLUSIONS}

A machine for harvesting sesame seeds was designed and fabricated. The sesame seed harvesting machine consists of 3 ropes, 5 pulleys, 6 chain sprockets and a 1HP motor along with crank shafts and steel frames and is operate manually. The machine is capable of harvesting the sesame seeds semi automatically with power as the source. In the current agricultural practices the sesame seeds as being cut manually with the help of specialized knife cutters by skilled farmers. The modern harvesting machines that are available are too large in size under compared to the size of sesame plant. In order to overcome these disadvantages this sesame harvesting machine can be introduced in the agricultural practices and it is reduce both human efforts and also the time consumption in harvesting an agricultural field. These it is concluded that, this project of sesame harvesting machine can be implemented in the agricultural field and it is designed with a concern for the farmers.

\section{REFERENCES}

1. Clyde L. Taylor, Chinoworth St., Sesame Seed Harvester, US patent no 4,266,393.

2. Clyde L. Taylor, W. Mineral King, Seed Harvesting Apparatus, US patent no 4,419,856.

3. Derald Ray Langham, San Antonio, TX (US), Pygmy Sesame Plants For Mechanical Harvesting, US Patent no 8,664,472 B2.

4. Omer L. Casey; Gordon G. Casey; Larry L. Casey, Crop Pickup And Seed Harvesting Device, US Patent no 5,134,837.

5. D. Yilmaz, I. Akinci and M.I. Cagirgan Effect of Some Threshing Parameters on Sesame Separation, CIGR E journal. Manuscript PM 08004, vol. x.

6. Alferov, S.A., Braginec, V.S., 1972. Threshing and grain separation in threshing units as a uniform probability-conditioned process. Traktory i sel chozmasiny. 42, 23-26.

7. Kanafojski, CZ., Karwowski, T., 1976.Agricultural machines, theory and construction. Vol 2,.301-317.

8. Kutzbach, H.D., 2003. Approaches for mathematical modeling of grain separation.Electronic-only proceeding of the international conference on crop harvesting and processing. Kentucky, USA.

9. Srivastava, A.K., Mahoney, W.T., West, N.L., 1990. The effect of crop properties on combine performance. Trans. of ASAE. 33, $63-72$.

10. Langham, D.G. 1944. “Natural and controlled pollination in sesame.” Journal of Heredity 8:254-256.

11. W. James Grichar, Peter A. Dotray and D. Ray Langham (2011). Weed Control and the Use of Herbicides in Sesame Production, Herbicides, Theory and Applications, M. Larramendy (Ed.), ISBN: 978-953-307-975-2.

12. Ramachandran, S., and D. Asokan. "Effect of Crop and Machine Parameters on Cutting Energy for Harvesting of Bengal Gram Crop." International Journal of Agricultural Science and Research (IJASR) 10.2 (2020):1-8.

13. Roul, Barsha Bindu, B. K. Mishra, and Nibedita Prusty. "Natural effect of micronutrient on growth and growth parameter of sesame oilseed crop." International Journal of Botany and Research (IJBR) 7.6 (2017):1- 4.

14. Potsangbam, Rajina, N. M. Kale, and N. P. Jangwad. "Knowledge and Adoption of Brinjal Growers about Recommended Cultivation Practices in Akola District." International Journal of Humanities and Social Sciences (IJHSS) 7.4 (2018):183-188. 
15. Roul, Barsabindu, B. K. Mishra, and Nibedita Prusty. "Physiological effect of micronutrient on yield and yield attributes of sesame crops of coastal Odisha condition." International Journal of Agricultural Science and Research (IJASR) 7.6 (2017): 17-22. 